\title{
A HÁLÓZATELEMZÉS LEHETŐSÉGEI AZ ÖNKÉNTES KUTATÁSBAN
}

BODOR-ERANUS ELIZA - BOCSKOR ÁKOS²

DOI: https://doi.org/10.53585/OnkSzem.2022.1.105-122

\section{Absztrakt}

Tanulmányunk azt a kérdést vizsgálja, hogy milyen lehetőségeket nyújthat a kapcsolathálózati megközelítés az önkéntesség-kutatás számára. Kiindulópontunk az önkéntesség definíciója, amelyet a különböző, a témával kapcsolatos paradigmák bemutatása követ. Tanulmányunk fókuszában a kapcsolathálózati megközelítés áll, kiemelve azt, hogy a kapcsolatháló-elemzés milyen lehetőségeket rejt az önkéntesség különböző formáinak vizsgálatában, illetve milyen előzményei vannak ennek a megközelítésmódnak a terület kutatásában. Ehhez egy rövid áttekintést nyújtunk a fontosabb hálózatelemzési kulcsfogalmakról is. Fontosnak találtuk kihangsúlyozni az önkéntesség-kutatás során felmerült innovatív kapcsolathálózati megközelítést is, melyet egy saját kutatásból származó példával szemléltetünk. Végezetül gyakorlati támpontokat szeretnénk nyújtani a szervezeti vezetők számára, bemutatva a kapcsolatháló-elemzés segítségével végzett kutatások hasznosulását a mindennapokban.

Kulcsszavak: kapcsolatháló-elemzés, önkéntesség, önkéntesség kutatásának paradigmái, innovatív kapcsolatháló-elemzés, önkéntesség a gyakorlatban,

\section{Network analysis outlook in the research of volunteerism}

\section{Eliza Bodor- Eranus - Ákos Bocskor}

\section{Abstract}

Our study explores the potential of the network-study approach in the research on volunteerism. Our starting point is the definition of volunteerism followed by the different paradigms related to the subject. Our study focuses on the network-study approach, highlighting the potential of network analysis in the study of different forms of volunteerism and the history of this approach in research in the field. For support, we also provide a brief overview of the key concepts in network analysis. We also wish to emphasize the innovative network approach that emerged during the research of volunteerism, which is illustrated by an example in our own research. Finally, we would like to provide practical guidance for organisational leaders, showing how research using network analysis can be utilized in everyday life.

Keywords: network analysis, volunteerism, paradigms of volunteerism research, innovative network approach, volunteering in practice

\footnotetext{
${ }^{1}$ Bodor-Eranus Eliza (PhD), szociológus, tudományos munkatárs, Társadalomtudományi Kutatóközpont, CSSRECENS

${ }^{2}$ Bocskor Ákos (PhD), szociológus, tudományos munkatárs, Társadalomtudományi Kutatóközpont, CSS-RECENS; egyetemi tanársegéd, Budapesti Corvinus Egyetem, Kommunikáció és Szociológia Intézet
} 


\section{BEVEZETÉS}

A kapcsolathálózati megközelítés viszonylag új szemlélete a nonprofit szektor és ezen belül is az önkéntességgel foglalkozó kutatásoknak. Habár a társadalmi kapcsolatok jelentőségét kezdettől fogva felismerték a szakterület kutatói, de a 2000-es évekig szinte csak statisztikai leírások születtek a témával kapcsolatban és azóta is inkább az ilyen jellegű kutatások dominálnak. Ugyanakkor a civil szféra - ezen belül az önkéntesség - egy „kapcsolati” jelenség is, Keane (2001) például úgy írja le a civil társadalmat, mint egy összekapcsolt, többrétegű társadalmi teret: lokális és globális kapcsolatokkal. Ilyen értelemben a társadalmi kapcsolatháló-elemzés az önkéntesség esetében egy olyan módszertani megközelítést takar, amelynek során mikroszinten (egyének közötti kapcsolatok), mezoszinten (csoportok közötti kapcsolatok), illetve akár makro-szinten (szervezetek közötti kapcsolatok) is vizsgálhatjuk a kapcsolódási pontokat.

E megközelítésnek azért van kiemelt jelentősége az önkéntes kutatások esetében, mivel ezen keresztül lehet megragadni a kapcsolati mintázatokat akár mindhárom vizsgálati szinten. A kapcsolatok sajátosságainak megismerése a hatékonyabb munkaszervezést, a segítő hálózatok létrejöttét és az önkéntesek motivációinak megismerését és erősítését egyaránt szolgálhatják. A releváns szakirodalmat elemezve úgy tűnik, hogy a kapcsolathálózati megközelítés jelenleg kiaknázatlan a hazai önkéntesség kutatásában.

Tanulmányunkban ezért arra szeretnénk felhívni a figyelmet, hogy milyen kapcsolathálóelemzési lehetőségek rejlenek az önkéntesség kutatásában. Írásunkban bemutatjuk az önkéntesség kutatásának paradigmáit, kiemelve a kapcsolathálózati kutatások eddigi eredményeit és rámutatva a további kutatási lehetőségekre. Végezetül az önkéntes szervezetek szempontjából tárgyaljuk a kapcsolathálózati megközelítés gyakorlati alkalmazásainak lehetőségeit.

\section{AZ ÖNKÉNTES KUTATÁSOK PARADIGMÁl}

Az önkéntesség fogalmának és területeinek meghatározására számtalan definíció, illetve taxonómia született már, ugyanakkor az általánosan elfogadott, tanulmányunk kiindulópontját képező definíció szerint: nem ellenszolgáltatásért, önkéntesen (szabad akaratból, belső indíttatásból) végzett tevékenység, amely más személy vagy a társadalom hasznát szolgálja. Fontos jellemző továbbá, hogy tervezett segítésről van szó, ahol az 
önkéntesek kinyilvánítják akaratukat és elkötelezettségüket, hogy másokon segítsenek, és erre a célra a szabadidejükből áldoznak időt (Clary et al. 1998).

Az önkéntességgel kapcsolatos elméleteket és empirikus kutatásokat Snyder és Omoto az általuk kidolgozott folyamatmodellben három fő csoportba sorolja:

- az önkéntesség előzményei,

- az önkéntesség tapasztalatai,

- az önkéntesség következményei;

Mindhárom „életszakasz” esetében megkülönböztetik az egyéni, az interperszonális, a szervezeti és a társadalmi szinteket (Snyder - Omoto 2008). A legtöbbet az előzmények szakaszt kutatták (Hustinx et al. 2010) vagyis azt, hogy kik és miért végeznek önkéntes tevékenységet. A motivációkat illetően a szakirodalmat áttekintve Snyder és Omoto a legfontosabb szempontok között a személyes értékeket, a közösségi és társadalmi ügyek iránti aggodalmat, a karrier előmozdítását, a személyes és szakmai kapcsolatháló bővítését, az egyéni fejlődés vágyát, illetve az önbecsülés növelését azonosítják be (Snyder - Omoto 2008). A hazai kutatások többek között a társadalmi értékeket (altruizmus, segítőszándék, együttérzés, elköteleződés egy társadalmi ügy mellett) kifejező érték-motivációk jelentőségét emelik ki (Bartal - Kmetty 2011). Ugyanakkor egyre inkább hangsúlyosabbá válnak az úgynevezett „új” motivációs tényezők, különösen a fiatalok körében, mint például az új ismeretek szerzése és hasznos készségek elsajátítása (Fényes 2021).

A Snyder és Omoto által felállított tipizálás szerint a kutatások második csoportja az önkénteseknek a tevékenységük során szerzett tapasztalataira fókuszál, többek között a más önkéntesekkel és a kedvezményezettekkel való interperszonális kapcsolatokra, az elvégzett munka, a személyes szükségletek és elvárások kielégítésének, valamint az önkéntes szervezetnek az önkéntes általi megítélésére, és másoknak az önkéntes munkával kapcsolatos (érzékelt) reakcióira (Snyder - Omoto 2008). Az önkéntes tapasztalatok pozitív és negatív érzéseket is generálnak: az empátia, a segítségnyújtás, a csoporthoz való tartozás és a különleges tevékenységek pozitív, míg a tevékenységhez kapcsolódó stigmatizáció (például az AIDS önkéntesek esetében), illetve a családtagok és barátok részéről érkező kritikái negatívan hatnak (Snyder et al. 1999; Snyder - Omoto 2008; Stürmer et al. 2005).

A következmények szakasza pedig az önkéntesek hozzáállásában, tudásában és viselkedésében az önkéntesség hatására bekövetkező változásokra, a nyújtott szolgáltatás élettartamára, valamint az önkéntesség hatékonyságának a megítélésére fókuszál (Snyder - 
Omoto 2008). A kutatási eredmények azt mutatják, hogy az önkéntesség pozitív hatással van a résztvevők önbecsülésére, tanulmányi eredményeire, bizalmára, egészségére és általános optimizmusára (Brown et al. 2003; Snyder - Omoto 2008; Thoits - Hewitt 2001).

Bár a szerzőpáros nem tér ki konkrétan a kapcsolatháló-elemzésre, de Snyder és Omoto (2008) folyamatmodelljébe jól illeszkedik ez a módszertan, hiszen mind az önkéntesség előzményei, mind pedig a tapasztalatok, de még a következmények esetében is indokolt volna megismerni a kapcsolatok számosságát, illetve összetételét, úgy a formális, mind az informális kapcsolatok tekintetében. Míg az előzményeknél a kapcsolathálózati várakozásokat (új szakmai, illetve személyes kapcsolatok bővítését/változását) lehetne feltárni, a következmények esetében pedig a kialakult kapcsolatok hatását a jóllétre, a tapasztalatok vonatkozásában lehetőség nyílik a kapcsolathálózat mikro-, mezo- és makroszintű vizsgálatára is, a formális és informális kapcsolatok esetében, továbbá olyan kapcsolathálózati mintázatok identifikálására, amelyek az önkéntes szervezeti múködés hatékonyságát javítanák. A tapasztalati szakaszban fontos, és eddig kapcsolathálózati módszerrel nem igazán vizsgált aspektus, az önkéntességből való kilépés. Haski-Leventhal és Bargal önkéntes fázisok és átmenetek modellje (volunteer stages and transitions model) öt különböző önkéntességi szakaszt és ezeket összekötő négy átmenetet és kétféle távozási folyamatot azonosít. A szerzőpáros (Haski-Leventhal - Bargal 2008) által identifikált korai kilépést például indokolhatják kapcsolathálózati sajátosságok is, ha például valakinek nem sikerül kapcsolati szempontból kellően integrálódni az önkéntes programba, és marginális vagy izolált szerepet tölt be a szervezeten belül.

A makroszintnek számító intézményi környezet és a társadalmi kontextus jelentősége sem újkeletű az önkéntességkutatásban, és ahogyan azt több szerző is hangsúlyozta, az önkéntességhez kapcsolódó olyan kulcsfontosságú értékeket, mint amilyen mások megsegítése, a szolidaritás, a méltányosságra és társadalmi igazságosságra való törekvés, ezeket sok kultúrában a vallási tanítások közvetítik. Az önkéntesség elterjedtségére és működésére nagy befolyást gyakorló kulturális hatások közé tartozik az is, hogy az adott társadalomban milyen individuális, illetve kollektív értékek dominálnak: az egyént tartják-e felelősnek teljes mértékben a saját jólétéért vagy inkább az állam, esetleg a civil/nonprofit szektor feladatának tartják-e a jólét biztosítását. Salamon és Anheier társadalmi eredet elmélete (social origins theory) az önkéntesség típusainak és elterjedtségének országok közötti különbségeit az eltérő jóléti rezsimekkel (liberális, szociáldemokrata, korporatívetatista) magyarázta, melyet empirikus adatokon is teszteltek (Salamon - Sokolowski 2003). 
Eszerint az önkéntesség legnagyobb mértékben a liberális és a szociáldemokrata rezsimekben fordul elő, de míg a liberális rezsimekben az állam alacsony szintú jóléti költekezései miatt erős nonprofit szektor és (szociális) szolgáltatás jellegű önkéntesség jellemző, addig a magas állami jóléti kiadásokkal rendelkező szociáldemokrata rezsimekben kisebb nonprofit szektor és elsősorban expresszív jellegű önkéntesség jellemző.

A különböző kulturális hatásokból és társadalmi értékrendekből származó eltérő perspektívák jól megjelennek Rochester és munkatársai felosztásában is, akik a motiváció, a tevékenységi terület, a szervezetei kontextus és az önkéntes szerepek alapján három különböző önkéntességgel kapcsolatos paradigmát különböztetnek meg (Rochester et al. 2010). Az első megközelítésmód a nonprofit paradigma, amely a szerzők szerint a domináns paradigma a társadalmi megítélés és a kutatók körében is. Ezt a megközelítésmódot az önkéntesség altruisztikus, filantropikus értelmezése jellemzi, mely elsősorban a társadalmi jólét (gondoskodás, támogatás, tanácsadás a rászoruló csoportok számára) területéhez kapcsolódó, a nonprofit szektorba tartozó professzionálisan szerveződő formális szervezetek által nyújtott szolgáltatásokra vonatkozik, ahol az önkéntesek specifikus, előre meghatározott szerepekre kerülnek kiválasztásra. A második megközelítésmód a civil társadalom paradigma, mely az önsegítésre és a kölcsönös segítségnyújtásra helyezi a hangsúlyt és a szociális segítségnyújtáson túlmutatóan a közpolitika más területeit is érinti, pl. várostervezés, közlekedésfejlesztés, környezetvédelem. Ebben a megközelítésmódban a szerzők szerint a teljesen önkéntes munkára épülő társulások jellemzőek a fizetett menedzsmenttel és személyzettel rendelkező nonprofit ügynökségekkel szemben. A harmadik perspektíva az önkéntesség, mint komoly szabadidős tevékenység (serious leisure) paradigma. Ide elsősorban az alkalmi, illetve a projekt-alapú önkéntesség (például egy kulturális esemény megszervezése) tartozik, melynek jellemző területei a múvészetek, a kultúra, a sport és a rekreáció. Mindez megvalósulhat önkéntes társulásokban és nagy összetett szervezetekben is. Az önkénteseket a belső motiváció jellemzi: az önkifejezés igénye, lelkesedés egy célért, a szükségesnek tartott tudás és készségek megszerzésének és gyakorlásának a vágya. A szerzők kiemelik, hogy léteznek hibrid formák is, amelyek több perspektíva jellemzőit is magukban foglalhatják (például a civil paradigma aktivizmusát és a nonprofit paradigma szolgáltató szemléletét is).

A tanulmány következő részében rátérünk a kapcsolathálózati szempontok vizsgálatára. $A$ (kvantitatív) hálózatelemzés elsősorban a zárt csoportokat tudja jól kezelni (gyakori 
módszertani hüvelykujjszabály a 80 százalék feletti kérdőív kitöltöttség), így elsősorban a formális, szervezeti keretek között megvalósuló önkéntességet, ezen belül is kiemelten az önkéntes tevékenység során megvalósuló tapasztalatokat tudja jól vizsgálni, bár ahogy korábban írtuk, az önkéntesség előzményei és következményei területén is fontos szerepet játszhatnak a társadalmi kapcsolatok. ${ }^{3}$

\section{A KAPCSOLATHÁLÓ-ELEMZÉS SZEREPE AZ ÖNKÉNTES KUTATÁSOKBAN}

\section{A kapcsolatháló-elemzés eredete és módszertana}

A kapcsolatháló-elemzés egy adott csoporton belül tárja fel a szereplők közötti kapcsolatokat valamilyen szempont szerint. A kapcsolathálózati kutatások gyökerei három tudományterületre vezethetőek vissza: a fizikára (Kurt Lewin és Fritz Heider úttörő kutatásai), a matematikára (különösen a gráfelméletre) és az antropológiára (szervezeti kapcsolathálók kutatása) (Kilduff - Tsai 2003). A társadalomtudományokban a kapcsolatháló-elemzés közvetlen előzményeinek a társadalmi beágyazódás (Granovetter 1973; Polányi 2001[1944]) és a társadalmi tőke (Bourdieu 1986; Coleman 1988; Putnam 1995; 2000) vizsgálatai tekinthetőek. Mark Granovetter „A gyenge kötések ereje” (1973) című múvében az „erős kötések” (például családtagok, közeli barátok) mellett a „gyenge kötések” (például lakóhelyi, munkahelyi ismerősök) vizsgálatának a fontosságára hívja fel a figyelmet, melyek összekötik társadalmi szinten az erős kötésekből álló csoportokat. A „gyenge kötések” szinte nélkülözhetetlenek a társadalmi életben való sikeres boldoguláshoz, azok az egyének, akik csak a saját közvetlen környezetükbe vannak erősen integrálva fontos információktól, lehetőségektől esnek el például a munkaerőpiacon (Granovetter 1973; 1995[1974]). James Coleman és Pierre Bourdieu munkásságukban a társadalmi kapcsolatokra, mint tőkejószágra tekintenek, amelyek bizonyos helyzetekben és körülmények között átkonvertálhatóak más tőkefajtákra például anyagi tőkére (Bourdieu 1986; Coleman 1988).

Ezek az elméleti megközelítések jól kombinálhatóak a kapcsolatháló-elemzés fogalomrendszerének két kulcsfogalmával, a reciprocitással és a tranzitivitással. Utóbbi fogalom arra utal, hogy az egyének az olyan kapcsolatokat preferálják, ahol egy vagy több erős

\footnotetext{
${ }^{3}$ Ugyanakkor mostanában a világjárvány okozta lezárások miatt jobban előtérbe került az informális önkéntesség is, Carlsen és munkatársai például az informális önkéntesség és a társadalmi kapcsolathálók viszonyát vizsgálták ebben az időszakban (Carlsen et al. 2021).
} 
kötést megosztanak, ellenkező esetben az egyensúly nélküli kapcsolatok kiegyenlítése irányába fognak cselekedni (lásd. strukturális kiegyensúlyozottság elmélete: Cartwright Harary 1956; Heider 1946). Egy rendkívül egyszerú példán szemléltetve ez azt jelenti, hogy amennyiben X személy (közeli) barátja Y-nak és Z-nek is, akkor erős strukturális nyomás alakul ki arra vonatkozóan, hogy $Y$ is barátja legyen Z-nek, ellenkező esetben a három tagból álló kiscsoportban már a meglévő kapcsolatok stabilitása is kérdésessé válhat. A kapcsolatok reciprocitása esetén a kiegyensúlyozatlanság következményei talán még egyértelmúbbek (például, ha $\mathrm{X}$ barátjának tekinti $\mathrm{Y}$-t, de $\mathrm{Y}$ nem tekinti barátjának $\mathrm{X}$-et). Egy további fontos kulcsfogalom a homofilia, vagyis az a feltételezés, hogy az egyének több (és szorosabb) kapcsolatot létesítenek a hozzájuk valamilyen szempont mentén (nem, etnikum, életkor, érdeklődési kör stb.) hasonló társaikkal. Ugyanakkor látható a fentebb leírtakból, hogy az egyének jelentős része (különösen a társadalmi hierarchia középső és alsóbb szintjein) gyakran akkor juthat új információkhoz, ha a sajátjától eltérő társadalmi csoportokkal ápol kapcsolatokat (heterofília).

A kapcsolatháló-elemzés kiindulási pontja lehet az egyén ${ }^{4}$ (ego hálózat) vagy a csoport. Egyéni szinten a kapcsolatháló-elemzés nemcsak a diádikus (két szereplő közötti) kapcsolatokat veszi figyelembe, hanem a triádokat (három aktorból álló viszonyrendszert) is, mely különbségtétel Georg Simmel német szociológus munkásságáig nyúlik vissza (Simmel 1902, 2009[1908]). Simmel szerint a triádok mindig magukban hordozzák a diádok alakításának lehetőségét, ami egyúttal azt is jelenti, hogy a harmadik tag a diádnak lesz alárendeltje. Ebben az esetben a bróker az a szereplő, aki „tertius gaudens”-ként úgy profitál, hogy közben fenntartja a két másik fél közötti távolságot. Ennek a kapcsolatnak sajátossága, hogy a bróker befolyással bír a két félre. Ezt a simmeli kapcsolatot gondolta tovább Fernandez és Gould, akik felállították 5 kapcsolódási típusból álló bróker-tipológiájukat a triádok esetében (Fernandez - Gould 1994). A társadalmi csoport szintjén a csoportot alkotó egyének közötti kapcsolat került feltérképezésre (Scott 2017; Wasserman - Faust 1994). Ennek során kiemelten fontos mutatók a hálózat sűrűsége és reciprocitása. A kapcsolathálózat sürüsége olyan mutató, amely a tagok kapcsolatait vizsgálja és akkor a legmagasabb, ha a hálózat minden tagja között van kapcsolat (például mindenki ismer mindenkit). A reciprocitás azt mutatja meg, hogy mennyire

\footnotetext{
${ }^{4}$ Az aktorok nem csak egyének, hanem nagyobb entitások például szervezetek vagy szervezeti egységek is lehetnek.
} 
viszonzottak a kapcsolatok, vagyis a kapcsolatok irányát veszi figyelembe, és akkor a legmagasabb, ha mindenkinek olyan kapcsolata van, amelyik a másik fél részéröl is kapcsolatként lett jelölve. Fontos mutató még a közelség mutatója, amelyik arra utal, hogy milyen távol található egyik egyén a másiktól, vagyis, ha nincs közvetlen kapcsolat közöttük, akkor hány köztes személyen keresztül tud eljutni egyik egyén a másikig. A sűrű kapcsolathálózatokkal szemben vannak olyan hálózatok, amelyek „strukturális lyukakat” tartalmaznak, vagyis egymástól jól elkülöníthető sűrű kapcsolatokból álló csoportok együttesét jelenti, egy-egy áthidalási lehetőséggel. Ezek a fajta csoportosulások kedveznek az információáramlásnak és az innovációnak (Burt 1999).

A társadalomtudományi, gazdasági és pszichológiai megközelítések kiemelt jelentőséget tulajdonítottak a kapcsolathálózatok azon szereplőinek, akik a hálózaton belüli pozíciójuknak köszönhetően valamilyen szempontból kulcsszerepet játszanak. Az első ilyen szereplő a kapcsolatok számának és erősségének köszönhetően a szociometriai sztár (Mérei 1996) vagy véleményvezér (Burt 1999) pozíciót betöltő aktor. A második szereplő az izolált csoportok közötti „híd” szerepét játszó és ezáltal az információáramlást biztosító „,bróker” (Fernandez Gould 1994). Burt (1999; 2005) véleménybrókereknek nevezte el azokat az egyéneket, akiknek olyan a kapcsolathálózatuk, hogy kapcsolataik révén strukturális lyukakat „hidalnak” át, és így információs előnyre tehetnek szert. Ezen szereplők kapcsolathálózati jellegű vizsgálata az innováció terjedését (innováció diffúziót) vizsgáló modellekben kaptak elsősorban magas figyelmet, amikor valamilyen prevenciós program (például drogprevenció) során azt vizsgálták, hogyan terjed az információ a csoport tagjai között, és azt találták, hogy a sok kapcsolattal rendelkező egyének (véleményvezérek) hatékonyan tudják terjeszteni a programot társaik között (például Valente - Davis 1999).

További kapcsolathálózati elemzés lehetősége rejlik abban, hogy az egyéneket egyéb csoportosulásokhoz vagy eseményekhez rendeljük, például egyes szervezetek képviselőinek valamely bizottsági tagsága vagy konferencia részvétele. Mátrixban elképzelve az egyes sorok a szervezeti képviselőket jelölik, az oszlopok pedig az egyes eseményeken való részvételt. Anheier és Katz (2004) szavaival élve, ezek a duális hálózatok olyan elemzési lehetőséget rejtenek, amelyek az adott eseményen való résztvevők kapcsolatait vizsgálhatják, vagy a résztvevők egyéb eseményeken való részvételi aktivitását, például az esernyő szervezetek esetében.

A kapcsolathálózat feltérképezése történhet kvalitatív módszerekkel (interjúk, narratív 
interjúk) vagy kvantitatív (kérdőíves) felméréssel. Rogers (1983:278) négy módszert említ a véleményvezetők identifikálására:

- a szociometriai módszert,

- az informátorok értékelésének módszerét,

- az önértékelés módszerét, és a

- résztvevő megfigyelést.

Kérdőíves felmérések esetében a leggyakoribb adatfelvételi mód a névgenerátor típusú kérdéseket alkalmazza, amikor bizonyos kérdések esetében a válaszadónak meg kell jelölnie azokat az embereket/eseményeket/szervezeteket, akikkel/amelyekkel kapcsolatban áll.

\section{Az önkéntesek kapcsolatainak vizsgálatai lehetőségei}

Tekintve, hogy a civil szféra, ezen belül az önkéntesség egy „kapcsolati” jelenség (Keane 2001:23 -24), az önkéntes kutatások elméleti megközelítései alapvetően a társadalmi tényezők (kontextus, integráció, szerepek), az egyéni jellemzők és az erőforrások témaköreit érintik (Einolf - Chambré 2011). A kapcsolatháló-elemzés relevanciája elsősorban a társadalmi tényezők esetében merül fel. A társadalmi kontextust illetően az önkéntesség társadalmi beágyazódásával kapcsolatban, az önkéntesek és más társadalmi csoportok, a társadalmi környezet közti kapcsolatok feltárása során (például Mellor et al. 2009), míg a társadalmi integráció tekintetében a fókusz az egyéni kapcsolatháló alakulásának vizsgálatán van. Ide tartoznak azok a kutatások, amelyek az önkéntesek kapcsolathálójának méretét és összetételének a hatásait vizsgálják. Figyelemre méltó például, hogy a több társadalmi kapcsolattal rendelkező egyéneket gyakrabban kérték fel önkéntes munkára (például Bekkers 2005; Okun et al. 2007), különösen, ha voltak már önkéntesként tevékenykedő barátaik (Wymer 1999 idézi Einolf - Chambré 2011). Emellett azok, akik más társadalmi tevékenységekben is részt vettek szintén nagyobb valószínűséggel önkénteskedtek (Putnam 2000). Az önkéntesség ugyanakkor nem csupán a társadalmi integráció következménye, hanem egyben az oka is lehet, mivel az önkéntesség új társadalmi kapcsolatok létrehozásának és ápolásának a terepét is jelentheti (például Prouteau - Wolff 2008). Az önkéntesség közösségi élményt nyújt, melynek során barátságok alakulhatnak ki a csapattagok között, a közös munka pedig erősítheti ezt a közösségi élményt: az önkéntesek általában támogatják egymást munkájukban, a kevesebb tapasztalattal rendelkező önkéntesek pedig támaszkodhatnak tapasztaltabb társaik segítségére (Toraldo et al. 2016). Mindezt 
alátámasztják azok a kutatások is, amelyek azt mutatják, hogy minél inkább támogatva érzik magukat az önkéntesek és minél jobbak az önkéntes szervezeten belül a kapcsolatok, annál kisebb valószínűséggel lépnek ki az önkéntességből (például Haski-Leventhal - Bargal 2008; Hidalgo - Moreno 2009; Maslanka 1996). Paik és Navarre-Jackson egy olyan modellt használtak, amelyben a társadalmi és szervezeti kötelékek, a vallási elköteleződés és az önkéntes szervezethez toborzó kapcsolatok képviselik a társadalmi kapcsolathálók diverzitását. Eredményeik alapján a toborzás erősen befolyásolja az önkéntességet, ami ugyanakkor összefüggésben áll a társadalmi kapcsolatok sokrétűségével, a szervezeti kötelékek számával és a vallásgyakorlással (Paik - Navarre-Jackson 2011 cit. Perpék 2011).

A társadalmi szerepekhez kapcsolódóan fontos kiemelni, hogy az önkéntesség maga is egy társadalmi szerep, melyet bátoríthatnak vagy elbizonytalaníthatnak más társadalmi szerepek (Einolf - Chambré 2011). Emellett az önkéntesség kompenzálhatja a más társadalmi szerepekben való teljesítés, önmegvalósítás hiányát és az életszakaszok közötti átmenetből származó társadalmi szerepvesztést, például a munkából nyugdíjba vonulás esetén (Einolf Chambré 2011).

Hazai vonatkozású kapcsolathálózati kérdőíves felmérést Tésenyi és munkatársai végeztek kórházi lelkigondozók körében (Tésenyi et al. 2017). A vallási alapon szerveződő önkéntesek esetében azt tapasztalták, hogy az együttmúködésre való készséget leginkább az adott személy ismertsége határozta meg, nem annyira a vallási csoport, amelyhez tartozott. Tanulmányukban azt is kiemelték, hogy a sikeres lelkigondozás esetében nagyon fontos lenne, hogy az önkéntesek kapcsolathálózata sűrű legyen, ekkor ugyanis a munka eredményességét tekintve a tudástranszfer hatékonyabban valósulhatna meg.

\section{Egy új megközelítés: Dinamikus kapcsolatháló-elemzés a rövid távú önkéntesség esetében}

Speciális helyzet áll fenn akkor, amikor az önkéntesek rövid távú munkában vesznek részt, például egy könnyűzenei fesztivál esetében. A könnyúzenei fesztiválok többnyire nem haladják meg az egy hetet, azonban az önkéntesek kapcsolatai ezen időtartam alatt jelentősen változhatnak. A fesztiválönkéntesek azért kerültek a tudományos kutatás középpontjába még a COVID-19 járványhelyzetet megelőzően -, mert sajátos szerepet játszanak a kulturális szórakoztatóiparban. Mindamellett, hogy a fesztiválok során az önkéntesek feladata a forprofit szektor (például könnyűzenei fesztivál szervezők) segítése, a részvételt erősen befolyásolja a fesztivál által képviselt értékek (például a könnyűzenei stílusok) és a saját 
személyes fejlődési lehetőségeik valamilyen kombinációja. Főképp a gyors technológiai fejlődésnek és digitalizációnak köszönhetően, a munkaerőpiacon a munkáltatók olyan tulajdonságokat helyeznek előtérbe az elméleti és gyakorlati jártasság mellett, mint például a munkavállalók fejlett problémamegoldó- és kommunikációs készségei (Levy - Murnane 2004). Utóbbiak esetében jó gyakorlati terep tud lenni a fiatal pályakezdők számára a fesztiválokon való (önkéntes) munkavégzés, ugyanis ez a terep épp az ismeretlen emberekkel történő sikeres együttmúködést és gyors problémamegoldást hívja életre. Azonban épp a fesztiválokon, a rendezvény időbeli korlátja miatt, az események rendkívül gyorsan zajlanak, az önkéntesek kapcsolathálózatai is dinamikusan alakulhatnak. Mivel a kapcsolathálózati felmérések általában statikus képet nyújtanak adott időpontban, adott szereplők közötti viszonyról, a dinamikusan alakuló kapcsolatokat érdemes dinamikus felméréseknek alávetni. A hazai fesztiválok esetében, a 2000-es évek óta számos kutatás született (például Ercsei et al. 2015; Gábor 2000; 2004; Gábor - Szemerszki 2006; Pap 2019; Pápay - Kis 2015), azonban kapcsolatháló-elemzést is alkalmazó kutatás csupán az Eötvös Lóránd Kutatási Hálózat Társadalomtudományi Kutatóközpontjában (korábban MTA TK) múködő CSS-RECENS kutatócsoport jóvoltából jött létre. 2018-ban a kutatócsoport a Fesztivál Önkéntes Központ önkénteseit vizsgálta a Sziget Fesztivál ideje alatt. Ebben a vizsgálatban a kutatás az önkéntes szervezet „középvezetői” rétegére, a mentorokra fókuszált, dinamikus kapcsolathálóelemzést alkalmazva (Bodor-Eranus et al. 2021). Az adatfelvétel a klasszikus kapcsolathálózati kutatásokban alkalmazott névgenerálási kérdésekkel történt, részben a munkahelyi elégedettségre és elköteleződésre, továbbá a pletykára vonatkozó kérdésekkel. Ezt egészítette ki az a naponta kétszer történő adatfelvétel, szintén névgenerálás módszerével, mellyel a kapcsolatok alakulását próbálta megragadni. Érdekessége volt az adatfelvételnek, hogy a napi kérdőíveket a mentorok okosórákon töltötték ki. A felmérésben a résztvevők száma 32 fő volt, ami megegyezett a mentorok, vagyis az önkéntes szervezet adott szervezeti szintjének összlétszámával. A kutatási eredmények felhívták a figyelmet a formális és informális együttműködési és kommunikációs hálózatok közötti különbségre. Továbbá a kapcsolatok dinamikus elemzésének köszönhetően láthatóvá vált, hogy míg kezdetben a formális kapcsolatháló igen sűrű volt, a fesztivál végéhez közeledve ennek sűrűsége csökkent. Vagyis míg kezdetben rengeteg munkahelyi jellegú információ terjedt a hálózatban a szervezeti formális kapcsolatokon keresztül, a munka rutinná válásával az ilyen jellegű információ terjedése csökkent. Az informális együttmúködési és kommunikációs hálózatok is 
erős intenzitást mutattak kezdetben, de a fesztivál végére dominálni látszottak a baráti kapcsolatok, megjelent a klikkesedés (2-3 személy közötti kölcsönös kapcsolatok).

Tekintve, hogy a 2018-as kutatás csupán az önkéntes szervezet egy szintjére összpontosított, 2019-ben a kutatócsoport kiterjesztette a kutatást a teljes önkéntes bázisra a Sziget Fesztivál ideje alatt. Ez 2019-ben közel 1200 önkéntest érintett a három szervezeti szinten: koordinátorok, mentorok és önkéntesek, beleértve az idegen nyelvű önkénteseket is. $A z$ adatfelvétel ezúttal is dinamikus kapcsolathálózati jellegú volt, vagyis naponta töltöttek ki a kapcsolathálózatra (formális és informális együttműködési és kommunikációs hálózatok) vonatkozó kérdéseket, azzal a különbséggel, hogy a kérdőívet az önkéntesek saját mobiltelefonjukon, egy applikációba ágyazva tölthették ki. Ennek a kutatásnak az elsődleges célja volt megvizsgálni, hogyan lehet ekkora mintán és ilyen kihívást jelentő terepen, mint a könnyűzenei fesztivál, sikeresen lebonyolítani az adatgyűjtést, emiatt az eredmények „pilot” jellegúek. A kapcsolathálózati kutatásokban akkor tekinthető sikeresnek az adatgyűjtés, illetve akkor lehet tudományos szempontból jól értékelni az eredményeket, ha a vizsgált populáció legalább 80 százaléka kitölti a kapcsolathálózatokra vonatkozó kérdéseket. A fesztivál végére majdnem 1400 kitöltött kérdőívvel rendelkeztünk (az adatbázis tisztítást követően), amelyek több mint 16000 kapcsolathálózati jelölést tartalmaztak. (A kérdőíves adatgyújtést további 98 interjúval egészítettük ki, amelyek segítettek az eredmények interpretálásában.) A kérdőív napi kitöltési rátája körülbelül 20 százalékos volt, tehát viszonylag alacsony a célzott $8 \S$ százalékos rátához képest, ugyanakkor sok tanulságot is levonhattunk a kutatási periódus végére, mind az adatfelvételi technika, mind pedig a kapcsolathálózatok tekintetében. $A z$ alacsony válaszadási ráta leginkább abból adódott, hogy a kérdőívet a kitöltők egy applikációba ágyazva tölthették ki. Az applikáció béta verziója abban az évben került először bevezetésre, az önkéntesek nem voltak hozzászokva a használatához, annak ellenére, hogy az étkezési kuponok érvényesítésére kellett használniuk. További nehézséget okozott az applikáció használatakor a nem megfelelő internet elérhetőség, illetve az okostelefonok hiánya néhány önkéntesnél. A technikai feltételek hiányát fokozta a kérdőívvel kapcsolatos információhiány is, ugyanis nem mindenki értesült arról, hogy a kérdőívet naponta ki kell tölteni, illetve az, hogy például sörkuponokra beváltható nyereményjátékban vesznek részt azok, akik a kérdőívet naponta kitöltik. Mindezen hiányosságok mellett értékes adatokkal gazdagodott a kutatócsoport. A dinamikus adatokat figyelembe véve azt tapasztaltuk, hogy a munkahelyi beszélgetések hálózata jóval sűrűbb volt a személyes beszélgetések hálózatához 
képest. Az önkéntes szervezet úgy látszik, hogy megtalálta a sikeres kommunikáció módját, a munkával kapcsolatos teendők és kérdések hatékonyan terjedtek a hálózaton belül, ennek köszönhetően a munkából fakadó problémák is hatékonyan és gyorsan orvosolhatókká váltak. A személyes témákban folytatott beszélgetéseket illetően, úgy tűnik, a teljes önkéntes szervezetben domináltak a közeli baráti kapcsolatok. Sok önkéntes eleve baráttal, barátokkal érkezett a programba, a velük fenntartott informális kommunikáció fontosnak bizonyult a program végéig, ugyanakkor jelentős számú új baráti kapcsolatok is kialakultak. Érdekessége volt a felmérésnek a normakövetésre, illetve normaszegésre vonatkozó kutatási dimenzió, amelynek során azt találtuk, hogy a kérdőívben az önkéntesek nem jelölték be a normaszegőket, azonban az interjúk során számtalan normaszegési helyzetről számoltak be, konkrétan megjelölve azokat a személyeket, akik nem tartották be a szabályokat. Nem szándékos, de értékes eredményt hozott magának a kérdőívnek a kitöltésére vonatkozó „Csalás”. A kérdőív kitöltéséért a válaszadók között naponta kisorsoltunk 20-60 főt (a kitöltési gyakoriságnak és a nyeremény mértékének - mely a kulacsoktól a sörkuponokig terjedtek megfelelően), akik másnap egy erre a célra felállított pultnál vehették át a nyereményeiket. Rendkívül népszerű volt a sörkupon mint ösztönző, ezért némely válaszadó azt a stratégiát választotta, hogy naponta többször is kitöltötte a kérdőívet. A „csalási” stratégia igen hatékonyan terjedt az egy munkakörben dolgozók körében, valószínúleg a szimpátián, bizalmon alapuló kapcsolatok esetében. A leggyakoribb ilyen jellegű kihágás 2-5 alkalommal fordult elő egy-egy személynél, de voltak kirívó esetek is, amikor valaki 198-szor küldte be a napi kérdőívet. Ez az attitűd szorosan összefüggött egyébként azzal a kutatási eredménnyel is, mely szerint az 1200 önkéntes esetében viszonylag nagy volt a redundancia, több munkakörben is tapasztalhatók voltak úgynevezett „üres járatok”, amikor valaki órákon keresztül unatkozott a saját kihelyezett posztján, vagyis volt ideje a kérdőív kitöltésével kísérletezni. A szervezeti szinten tapasztalt redundáns helyzetek feltárásai egyébként óriási tanulsággal jártak a Fesztivál Önkéntes Központ számára is, a szervezeti hatékonyság növelése érdekében a feladatok újragondolása már folyamatban volt.

\section{ÖSSZEGZÉS}

Az önkéntes tevékenység olyannyira meghatározó dimenzióját alkotják a kapcsolatok, hogy maga az önkéntes munka nem jöhetne létre, ha az önkéntesek nem állnának kapcsolatban 
azokkal, akiknek segíteni szeretnének, illetve akikkel együtt segíteni szeretnének. Annak ellenére, hogy a kapcsolatok jelentőségét az önkéntességgel foglalkozó kutatások már a kezdetektől fogva hangsúlyozták, a kapcsolathálózati megközelítés csupán az elmúlt években gyürüzött be a tudományterületre. A kutatók elkezdték felismerni azt, hogy a hatékony önkéntesség kialakításában (akár a toborzás, akár a motiváció, vagy hatékony munkavégzés tekintetében) kulcsszerepet játszik a kapcsolathálózat megismerése.

Fontos kiemelni, hogy ugyan vannak kezdeményezések annak leírására, hogy a kapcsolathálóelemzés hogyan hasznosítható a gyakorlatban egy civil vagy önkéntes szervezet esetében, azonban jelenleg ezen a téren is vannak fehér foltok. Összesítve az általunk feltérképezett irodalmat, a következőkben megpróbáljuk összefoglalni a gyakorlati hasznosulás irányvonalait.

- Az eddigi kutatások alapján úgy túnik, hogy a civil szervezetek összekapcsoltsága (interconnectivity) viszonylag gyenge világszinten. Miközben a „kis világ” (small wolrd) elméletében Milgram (1967) kimutatta, hogy az egyének egymástól vett távolsága átlagosan 6 lépésre ( 6 köztes kapcsolatra) szorítkozik, addig a civil szervezetek körében mért hasonló kutatás (Anheier - Katz 2004) 5158 civil szervezetet vizsgálva, a köztük levő átlagos távolságot 7,3 lépésnek találta. Hazai szinten erre vonatkozóan nem történt még felmérés, azonban a civil szervezetek tevékenységének láthatósága érdekében, nagyon hasznos lenne kapcsolatháló-elemzéssel rámutatni, hogyan lehetne erősíteni a szervezetek közötti kapcsolatokat.

- A civil vagy önkéntes szervezetek beágyazottságát illetően szintén előremutató lehet a kapcsolatháló-elemzés, akár a szervezetek kapcsolatait vizsgálva a környezetükkel, akár a szervezetek és feladatok közötti kapcsolatok elemzése szempontjából. Ez a fajta vizsgálat nemcsak a szervezeti sajátosságokat tárhatja fel, hanem az esetleges regionális különbséget is. Például (Anheier - Katz 2004) azt találták, hogy a nyugati civil szervezetek (például Svájcban) sűrűbb kapcsolatokkal rendelkeznek, míg a déli országokban (például Etiópiában) a kapcsolatok globálisabbak, hiszen perifériális helyzetükből fakadóan érdekükben áll a több kapcsolattal rendelkező nyugati szervezetekkel való kapcsolatépítés. Ilyen szempontból Magyarországon a regionális különbségek vizsgálatának is lenne létjogosultsága, rámutatva, hogy mely szervezetek esetében érdemes erősíteni a vidéki jelenlétet, hol érdemes több önkéntest toborozni.

- A kapcsolatháló-elemzés további gyakorlati hasznosulása szervezetfejlesztési szempontú, 
az önkénteseket foglalkoztató szervezetek számára. A szervezeten belüli formális és informális együttmúködési és kommunikációs kapcsolatok feltérképezése rávilágíthat a szervezeti múködés hiányosságaira, például, ha valamelyik szervezeti egység nem kellően integrált, vagy ha valamelyik szervezeti egységben a tagok marginalizálódnak. A szervezeti elégedettséget vagy elköteleződést rávetítve a kapcsolathálózatokra arra is fény derülhet, ha valamelyik szervezeti egységben elterjed az elégedetlenség és az esetleg éppen a szervezeti egység központi szereplőjét érinti, akkor megfontolandóvá válhat az egység vezetőjének leváltása. További aspektus lehet a pletyka terjedése szervezeten belül, ami szintén jól modellezhető egy kapcsolathálózati felméréssel, ugyanis a negatív pletyka terjedése káros lehet a szervezeti múködésre. Végül, a teljesítmény is jól levetíthető a szervezeti kapcsolathálóra, ugyanis lehetővé válik azon szereplők azonosítása, akik teljesítmény szempontjából kiemelkedők, de a szervezeti kapcsolathálóban marginális szerepet töltenek be, a motiváció szempontjából ezek fontos információval tudnak bírni egy szervezeti vezető számára.

- A szervezeti tagok társadalmi beágyazottságának vizsgálata is fontos gyakorlati szempontokat tárhat fel. A legtöbb önkéntes munka esetében fontos a megsegített célcsoportot képező egyénekkel való kapcsolatépítés, amit egy megfelelő kapcsolathálózati adatgyűjtés jól tud illusztrálni (melyik önkéntes hány megsegített emberrel tartja a kapcsolatot). Ugyanakkor, mivel a szakirodalomból ismert, hogy az önkéntesek hajlamosak több szervezet keretein belül történő önkéntes munkában is részt venni, fontos lenne látni, hogy a munka és feladat a kapcsolatok során hogyan valósul meg. Ez az önkéntes munkatervezéshez, kapacitásnöveléshez vagy csökkentéshez nyújt fontos vezetői támpontokat.

Végül fel szeretnénk hívni a civil és önkéntes szervezetek vezetőinek figyelmét arra, hogy a digitális technológiai környezet folyamatosan és rendkívül gyorsan változik, és ma már egyre több olyan adatgyújtési módszer is rendelkezésünkre áll, amelyek a kapcsolatháló-elemzést kiegészítik, ezáltal növelve a szervezeti hatékonyságnak és a munka eredményességének szervezési lehetőségeit. Ilyen szempontból újszerű megközelítésnek tekinthető az online térben megvalósult önkéntes kapcsolathálók vizsgálata, továbbá a rövid- és hosszú távú önkéntesség esetében a kapcsolatháló szerepének és jellemzőinek vizsgálata például ismétlődő adatfelvételekkel (lásd.: dinamikus kapcsolatháló-elemzés), vagy olyan kiegészítő adatfelvételekkel, mint például az önkéntes tevékenységhez kapcsolódó passzív adatgyűjtés 
(pl. lépésszámlálás, pulzusmérés). A tudományos kutatási ambíció egyre nagyobb mértékben veszi figyelembe a passzív adatgyújtésből származó adatokat, melyek nagyon hasznos kiegészítői a kapcsolatháló-elemzésnek, ennek technikai feltételeire tesz kísérletet jelenleg a TK CSS-RECENS kutatócsoport is.

\section{IRODALOM}

Anheier, Helmut - Katz, Hagai (2004): Network Approaches to Global Civil Society. In. Anheier, H. Glasius, M. - Kaldor, M. (eds.): Global Civil Society 2004/5. Global Civil Society - Year Books. London: SAGE, pp. 206-221.

Autor, David H. - Levy, Frank - Murnane, Richard J. (2003): The Skill Content of Recent Technological Change: An Empirical Exploration. The Quarterly Journal of Economics, 118(4) pp. 1279-1333. DOI: 10.1162/003355303322552801

Bartal Anna Mária - Kmetty Zoltán (2011): A magyar önkéntesek motivációi. Civil Szemle, 8(4) pp. 730.

Bekkers, René (2005): Participation in Voluntary Associations: Relations with Resources, Personality, and Political Values. Political Psychology, 26(3) pp. 439-454.

Bodor-Eranus Eliza - Bocskor Ákos - Szvetelszky Zsuzsanna - Takács Károly - Vit Eszter -Samu Flóra Galántai Júlia - Pétervári Judit (2021): Professzionalizálódó fesztivál önkéntesség egy kapcsolathálózati kutatás tükrében: Esettanulmány. Önkéntes Szemle, 1(2) pp. 110-124. DOI: 10.53585/OnkSzem.2021.2.110-124

Bourdieu, Pierre (1986): The forms of capital. In. Richardson, J. (ed.): Handbook of Theory and Research for the Sociology of Education. Westport, CT: Greenwood, pp. 241-258.

Brown, Stephanie L. - Nesse, Randolph M. - Vinokur, Amiram D. - Smith, Dylan M. (2003): Providing Social Support May Be More Beneficial Than Receiving It: Results From a Prospective Study of Mortality. Psychological Science, 14(4) pp. 320-327. DOI: 10.1111/1467-9280.14461

Burt, Ronald S. (1999): The Social Capital of Opinion Leaders. The ANNALS of the American Academy of Political and Social Science, 566(1) pp. 37-54. DOI: 10.1177/000271629956600104

Burt, Ronald S. (2005): Brokerage and Closure. An Introduction to Social Capital. Oxford: Oxford University Press.

Carlsen, Hjalmar Bang - Toubøl, Jonas - Brincker, Benedikte (2021): On solidarity and volunteering during the COVID-19 crisis in Denmark: the impact of social networks and social media groups on the distribution of support. European Societies, 23(sup1) pp. S122-S140. DOI: 10.1080/14616696.2020.1818270

Cartwright, Dorwin - Harary, Frank (1956): Structural balance: a generalization of Heider's theory. Psychological Review, 63(5) pp. 277-293. DOI: 10.1037/h0046049

Clary, E. Gil - Snyder, Mark - Ridge, Robert D. - Copeland, John - Stukas, Arthur A. - Haugen, Julie Miene, Peter (1998): Understanding and assessing the motivations of volunteers: A functional approach. Journal of Personality and Social Psychology, 74(6) pp. 1516-1530. DOI: 10.1037/00223514.74.6.1516

Coleman, James S. (1988): Social Capital in the Creation of Human Capital. American Journal of Sociology, 94., pp. 95-120. 
Einolf, Christopher - Chambré, Susan M. (2011): Who volunteers? Constructing a hybrid theory. International Journal of Nonprofit and Voluntary Sector Marketing, 16(4) pp. 298-310. DOI: 10.1002/nvsm.429

Ercsei Kálmán - Pakot Ágnes - Veres Valér (2015): Sziget 2014 (pdf). http://mentalmap.org/sziget2014/wp-content/uploads/2015/03/sziget2014-

jelentes_ercsei_pakot_veres.pdf Letöltve: 2022.01.30.

Fényes Hajnalka (2021): Az elmúlt tíz év kutatási eredményei a felsőoktatási hallgatók önkéntességéről. Önkéntes Szemle, 1(1) pp. 56-68. DOI: 10.53585/OnkSzem.2021.1.56-68

Fernandez, Roberto M. - Gould, Roger V. (1994): A Dilemma of State Power: Brokerage and Influence in the National Health Policy Domain. American Journal of Sociology, 99(6) pp. 1455-1491.

Gábor Kálmán (2000): A Középosztály Szigete. Szeged: Belvedere Meridionale Kiadó.

Gábor Kálmán (2004): Sziget kutatások 2000-2004. Erdélyi Társadalom, 2(2) pp. 229-269.

Gábor Kálmán - Szemerszki Marianna (2006): Sziget Fesztivál 2005: Az új fiatal középosztály és az élettervezés. Kutatás Közben. Budapest: Felsőoktatási Kutatóintézet. https://mek.oszk.hu/09800/09872/09872.pdf Letöltve: 2022.01.30.

Granovetter, Mark (1995): Getting a Job: A Study of Contacts and Careers (2d edition). Chicago, IL: University of Chicago Press.

Granovetter, Mark (1973): The Strength of Weak Ties. American Journal of Sociology, 78(6) pp. 13601380.

Haski-Leventhal, Debbie - Bargal, David (2008): The volunteer stages and transitions model: Organizational socialization of volunteers. Human Relations, 61(1) pp. 67-102. DOI: 10.1177/0018726707085946

Heider, Fritz (1946): Attitudes and Cognitive Organization. The Journal of Psychology, 21(1) pp. 107112. DOI: $10.1080 / 00223980.1946 .9917275$

Hidalgo, M. Carmen - Moreno, Pilar (2009): Organizational socialization of volunteers: the effect on their intention to remain. Journal of Community Psychology, 37(5) pp. 594-601. DOI: 10.1002/jcop.20317

Hustinx, Lesley - Handy, Femida - Cnaan, Ram A. (2010): Volunteering. In. Taylor, R. (ed.): Third Sector Research. New York, NY: Springer, pp. 73-89. DOI: 10.1007/978-1-4419-5707-8_7.

Keane, John (2001): Global Civil Society? In. Anheier, H. - Marlies, G. - Mary, K. (eds.): Global Civil Society 2001. Oxford: Oxford University Press, pp. 23-47. https://globalcivilsociety.org/chapters/global-civil-society/ Letöltve: 2022.01.30.

Kilduff, Martin - Tsai, Wenpin (2003): Social Networks and Organizations. London: SAGE. DOI: $10.4135 / 9781849209915$

Maslanka, H. (1996): Burnout, social support and AIDS volunteers. AIDS Care, 8(2) pp. 195-206. DOI: 10.1080/09540129650125876

Mellor, David - Hayashi, Yoko - Stokes, Mark - Firth, Lucy - Lake, Lucy - Staples, Michael - Chambers, Sue - Cummins, Robert (2009): Volunteering and Its Relationship With Personal and Neighborhood Well-Being. Nonprofit and Voluntary Sector Quarterly, 38(1) pp. 144-159. DOI: 10.1177/0899764008317971

Mérei Ferenc (1996): Közösségek Rejtett Hálózata. Szociometriai Értelmezés. Budapest: Osiris.

Milgram Stanley (1967): The Small World Problem. Psychology Today, 1(1) pp. 61-67.

Okun, Morris A. - Pugliese, John - Rook, Karen S. (2007): Unpacking the relation between extraversion and volunteering in later life: The role of social capital. Personality and Individual Differences, 42(8) pp. 1467-1477. DOI: 10.1016/j.paid.2006.10.020 
Pap Viktória (2019): Researching the spirit of place. Mental mapping on Sziget festival. Corvinus Journal of Sociology and Social Policy, 10(1). DOI: 10.14267/CJSSP.2019.1.6

Pápay Boróka - Kis Balázs (2015): Sziget - Nyelvi tájkép - 2014.

http://mentalmap.org/sziget2014/wp-content/uploads/2015/03/Linguistic-Landscape_honlapraP\%C3\%A1pay-Bor\%C3\%B3ka_-Kis-Bal\%C3\%A1zs-3.0-1.pdf Letöltve: 2022.01.30.

Perpék Éva (2011): Önkéntesség és közösségfejlesztés. PhD értekezés. Budapesti Corvinus Egyetem, Budapest. http://phd.lib.uni-corvinus.hu/675/1/Perpek_Eva.pdf Letöltve: 2022.01.30.

Prouteau, Lionel - Wolff, François-Charles (2008): On the relational motive for volunteer work. Journal of Economic Psychology, 29(3) pp. 314-335. DOI: 10.1016/j.joep.2007.08.001

Putnam, Robert D. (1995): Bowling Alone: America's Declining Social Capital. Journal of Democracy, 6(1) pp. 65-78.

Putnam, Robert D. (2000): Bowling Alone: The Collapse and Revival of American Community. 1st edition. London: Touchstone Books by Simon \& Schuster.

Rochester, Colin - Paine, Angela Ellis - Howlett, Steven (2010): Volunteering and Society in the 21st Century. London: Palgrave Macmillan. Available at: DOI: 10.1057/9780230279438

Rogers, Everett M. (1983): Diffusion of Innovations. New York and London: The Free Press.

Salamon, Lester M. - Sokolowski, S. Wojcieh (2003): Institutional Roots of Volunteering. In: Dekker, P.

- Halman, L. (eds): The Values of Volunteering: Cross-Cultural Perspectives. Nonprofit and Civil Society Studies. Boston, MA: Springer US, pp. 71-90. DOI: 10.1007/978-1-4615-0145-9_5

Scott, John (2017): Social Network Analysis. London: SAGE Publications Ltd. DOI: 10.4135/9781529716597

Simmel, Georg (1902): The Number of Members as Determining the Sociological form of the Group. II. American Journal of Sociology, 8(2) pp. 158-196.

Simmel, Georg (2009): Sociology: Inquiries into the Construction of Social Forms, 2 Volume Set. Leiden - Boston: Brill.

Snyder, Mark - Omoto, Allen M. (2008): Volunteerism: Social issues perspectives and social policy implications. Social Issues and Policy Review, 2(1) pp. 1-36. DOI: 10.1111/j.1751-2409.2008.00009.x

Snyder, Mark - Omoto, Allen M. - Crain, A. Lauren (1999): Punished for their Good Deeds: Stigmatization of AIDS Volunteers. American Behavioral Scientist, 42(7) pp. 1175-1192. DOI: 10.1177/0002764299042007009

Stürmer, Stefan - Snyder, Mark - Omoto, Allen M. (2005): Prosocial Emotions and Helping: The Moderating Role of Group Membership. Journal of Personality and Social Psychology, 88(3) pp. 532546. DOI: 10.1037/0022-3514.88.3.532

Tésenyi Tímea - Lukács Ágnes - Járay Márton - Lukács Gergely (2017): Kapcsolathálózati kutatás magyarországi kórházi lelkigondozók körében. Embertárs, 2017(1) pp. 5-22.

Thoits, Peggy A. - Hewitt, Lyndi N. (2001): Volunteer work and well-being. Journal of Health and Social Behavior, 42(2) pp. 115-131.

Toraldo, Maria Laura - Contu, Alessia - Mangia, Gianluigi (2016): The Hybrid Nature of Volunteering: Exploring Its Voluntary Exchange Nature at Music Festivals. Nonprofit and Voluntary Sector Quarterly, 45(6) pp. 1130-1149. DOI: 10.1177/0899764016649688

Valente, Thomas W. - Davis, Rebecca L. (1999): Accelerating the Diffusion of Innovations Using Opinion Leaders. The ANNALS of the American Academy of Political and Social Science, 566(1) pp. 55-67. DOI: 10.1177/000271629956600105

Wasserman, Stanley - Faust, Katherine (1994): Social Network Analysis: Methods and Applications. New York, US: Cambridge University Press. DOI: 10.1017/СВO9780511815478 